\title{
EDUKACJA INFORMACYJNA NA UNIWERSYTECIE \\ - POMIĘDZY IDEAŁEM A RZECZYWISTOŚCIĄ. Czy można w Polsce wyKorzystać doświadczenia amerykańskie?
}

\author{
Maria Bosacka \\ bosacka@onet.eu
}

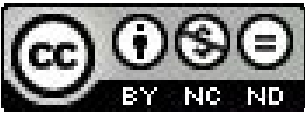

Rozwój technologii informatycznych i komunikacyjnych w początkach XXI wieku przyniósł ze sobą zarówno szereg obietnic, jak i problemów. Nowe technologie usprawniły komunikację, styl uczenia, prowadzenie badań naukowych, dały nowe możliwości rozwoju osobistego i zawodowego. Z drugiej jednak strony wpłynęły na lawinowy wzrost ilości dostępnej informacji i powstanie tzw. szumu informacyjnego. Konieczne stało się kształcenie użytkowników w zakresie obsługi nowych technologii informacyjno-komunikacyjnych i wykorzystania elektronicznych zasobów wiedzy. Problem ten dotyka szczególnie uczelni wyższych, a jego rozwiązaniem zajmują się w dużej mierze biblioteki uczelniane. To właśnie na nich spoczywa odpowiedzialność za przygotowanie studentów do samodzielnego zdobywania wiedzy. W ostatnich latach w Polsce popularność zdobył termin information literacy (IL), tłumaczony jako umiejętności informacyjne lub alfabetyzacja informacyjna ${ }^{1}$. Chodzi o nauczenie określania indywidualnych potrzeb informacyjnych (umiejętność definiowania problemu i stawianie właściwych pytań), poszukiwania i skutecznego oraz efektywnego docierania do pożądanej informacji, a także jej krytycznej oceny i praktycznego wykorzystania zgodnie z zasadami etyki. Zdobycie umiejętności informacyjnych jest niezbędne nie tylko w procesie kształcenia akademickiego, ale także, a może nawet dużo bardziej, w procesie kształcenia ustawicznego. Pytanie tylko, czy studenci gotowi są podjąć to wyzwanie i kto ma ich wspierać (szkolić)?

Problem information literacy w polskim szkolnictwie wyższym nie doczekał się kompleksowych rozwiązań. Na świecie zresztą również brak ujednoliconych programów międzynarodowych czy narodowych pomimo doceniania wagi tego problemu. W 2004 r. odbyła się w Buenos Aires 70. Generalna Konferencja IFLA: Biblioteki narzędziem edukacji i rozwoju, wśród poruszanych tematów ważne miejsce znalazły zagadnienia związane z IL. Rola umiejętności informacyjnych w procesie kształcenia ustawicznego została dostrzeżona również przez ministrów edukacji 29 krajów europejskich, którzy w 1999 r. podpisali Deklarację Bolońską. Dokumentem związanym z Deklaracją jest Komunikat ze spotkania europejskich ministrów ds. szkolnictwa wyższego, przyjęty w Pradze w 2001 r., w którym znalazło się stwierdzenie, że „kształcenie ustawiczne stanowi zasadniczy element europejskiego obszaru szkolnictwa wyższego" ${ }^{\prime 2}$. Konsekwencją tego stwierdzenia była propozycja wprowadzenia zajęć z IL do systemu punktów kredytowych ECTS (Europejski System Transferu Punktów Kredytowych).

Jak już wspomniano, ze względu na brak szerokich międzynarodowych i narodowych programów nauczania IL wiele instytucji opracowuje swoje standardy. Do przodujących w tym za-

E. Rozkosz, Alfabetyzacja informacyjna, http://alfabetyzacjainformacyjna.blogspot.com/2011/information-literacy-po-polski-czyli.html, 5.05.2011.

Deklaracja Bolońska i co dalej: zbiór komunikatów, wytycznych i sugestii. Materiaty ze strony internetowej MENiS http:// www.menis.gov.pl, Konferencja Rektorów Uniwersytetów Polskich, Poznań 2004, s. 33, http://www.uka.amu.edu.pl/pictures/bolonia.pdf, 5.05.2011.

3 D. Konieczna, Biblioteka akademicka jako instytucja promujaca kształcenie, http://www.library.put.poznan.pl/2005/ pdf/3_4.pdf, 5.05.2011. 
kresie należy bibliotekarstwo amerykańskie, gdzie umiejętnościami informacyjnymi zainteresowano się już ponad 30 lat temu. W 2000 roku w Association of College \& Research Libraries (ACRL) opracowano dokument pt. Information literacy competency standards for higher education. Znalazło się w nim 5 podstawowych standardów:

„Student posiadający umiejętności informacyjne potrafi określić istotę i zakres potrzebnych informacji.

Student posiadający umiejętności informacyjne potrafi uzyskać potrzebne informacje w sposób sprawny i skuteczny.

Student posiadający umiejętności informacyjne potrafi krytycznie ocenić informację i jej źródła oraz włączyć wyselekcjonowaną informację w zakres swojej wiedzy i systemu wartości.

Student posiadający umiejętności informacyjne potrafi za pomocą zdobytych informacji osiągnąć określone cele, zarówno indywidualnie, jak i jako członek grupy.

Student posiadający umiejętności informacyjne rozumie wiele ekonomicznych, prawnych i społecznych uwarunkowań dotyczących korzystania z informacji oraz zdobywa i korzysta z informacji w sposób etyczny i zgodny z prawem" ${ }^{\prime \prime}$.

Zainteresowanie problematyką IL w USA widoczne jest między innymi w ilości badań, prowadzących nieraz do zaskakujących wniosków. Warto przytoczyć niektóre z nich w sytuacji braku polskich badań $w$ tym zakresie.

Na uczelniach wyższych nauczanie umiejętności informacyjnych spada na barki bibliotek akademickich. Tylko na nielicznych uniwersytetach IL jest traktowana jako pełnoprawny przedmiot. Z drugiej strony na szkolenia biblioteczne przeznacza się zbyt mało czasu, aby można było przekazać wiedzę wykraczającą poza podstawową znajomość obsługi katalogu OPAC czy korzystania z baz bibliotecznych ${ }^{5}$. Na uwagę zasługują również badania efektywności nauczania umiejętności informacyjnych różnymi metodami. Karen Anderson i Frances A. May z Uniwersytetu Północnego Teksasu w Denton przeprowadziły badania polegające na porównaniu efektywności różnych form szkolenia studentów: tradycyjnych kursów w formie wykładów i ćwiczeń z kursami online oraz z kursami łączonymi - połączeniem tradycyjnego wykładu z kursem komputerowym $^{6}$. Wszystkie formy okazały się równie skuteczne, a przy okazji odnotowano wysoki poziom umiejętności informacyjnych u studentów jeszcze przed rozpoczęciem kursu. Doprowadziło to do wniosków, że programy szkoleń muszą być dostosowane do studentów zarówno początkujących, jak i zaawansowanych w dziedzinie IL. Kolejny problem to zbyt mały nacisk na wykształcenie u studentów postawy krytycznej wobec zdobytej informacji. Za najbardziej efektywną strategię nauczania uznano ścisłą współpracę bibliotekarzy i pracowników naukowych. Bez takiej współpracy bibliotekarze mają ograniczone możliwości wdrażania standardów IL ARCL. Rolą bibliotekarza jest dostarczenie ogólnych wiadomości z zakresu IL, ze szczególnym naciskiem na procesy gromadzenia i oceny informacji z różnych dziedzin. Rola pracownika naukowego polega na kształceniu umiejętności informacyjnych studentów ściśle związanych z daną dyscypliną naukowaa, pokazanie związków pomiędzy zmieniającym się kontekstem informacyjnym a znaczeniem danych specyficznych dla danej dyscypliny. Współpraca pomiędzy bibliotekarzami a naukowcami jest kluczem do skutecznego nauczenia studentów umiejętności informacyjnych

$4 \quad$ http://www.ala.org/acrl/ilomstan.ala/acrl/acrlstandards, 5.05.2011.

5 D. Ward, Revisioning information literacy from lifelong meaning," The Journal of Academic Librarianship" 2006, nr 4 (32), s. 402.

6 K. Anderson, F. A. May, Does the Method of Instruction Matter? An Experimental Examination of Information Literacy in the Online, Blended and Face-to-Face Classrooms, "The Journal of Academic Librarianship" 2010, nr 6 (36), s. 495-500. 
oraz do wykorzystania zdobytej przez nich wiedzy zarówno w procesie edukacji na uczelni, jak i w życiu codziennym oraz w procesie kształcenia ustawicznego ${ }^{7}$.

Inną ciekawą formą rozwijania kompetencji informacyjnych na uniwersytetach amerykańskich jest mentoring i to zarówno w odniesieniu do studentów, jak i bibliotekarzy. Ten drugi aspekt jest o tyle interesujący, że wpisuje się w nowoczesny pogląd postrzegający bibliotekę jako instytucję uczącą się. Mentoring to pojęcie, $\mathrm{w}$ odniesieniu do którego nie ma ujednoliconej terminologii - istnieje tyle definicji, ilu trenerów, mentorów i nauczycieli. We wszystkich jednak pojawiają się pojęcia: wsparcie, wskazywanie drogi, pomoc. Eric Parsloe i Monika Wray określają mentoring jako „proces wspierający naukę i rozwój, a przez to doskonalenie, zarówno w odniesieniu do jednostek, zespotów, jak i całych firm ${ }^{\prime \prime}$. Jest to także szczególnego rodzaju relacja, której cechami są obiektywność, wiarygodność, zaufanie, szczerość i dyskrecja'. Na uczelniach amerykańskich, w odniesieniu do kształcenia umiejętności informacyjnych, mentorami są zarówno studenci starszych roczników, jak i naukowcy. Ci pierwsi najczęściej opiekują się studentami rozpoczynającymi naukę, ci drudzy stają się mentorami dla studentów i młodszych pracowników naukowych, prowadzących badania w ramach konkretnej dyscypliny naukowej i dzięki własnej wiedzy i doświadczeniu mogą wspierać merytorycznie podopiecznych. Przykładem ciekawych rozwiązań są działania na Uniwersytecie w Idaho, gdzie wprowadzono nowy model mentoringu - peer mentoring, zakładający odejście od formalnego, dydaktycznego i hierarchicznego amerykańskiego modelu mentor-podopieczny, na rzecz modelu polegającego na połączeniu osób niedoświadczonych z osobami posiadającymi odpowiednią wiedzę na warunkach równoprawnych i utworzeniu niewielkiej społeczności uczącej się (Community of Practice), złożonej ze studentów i naukowców o podobnych zainteresowaniach oraz chęci do uczenia się i dzielenia wiedzą w przyjaznym otoczeniu. Osiągnięto w ten sposób poprawę w komunikowaniu się i wymianie doświadczeń, szczególnie ważnych we współpracy interdyscyplinarnej. Badacze K. J. Henrich i R. Attebury podkreślili zalety poczucia silnej więzi społecznej pomiędzy członkami grupy i zbudowanemu w ten sposób wzajemnemu zaufaniu. Trzeba dodać, że udział w projekcie był całkowicie dobrowolny. Sukces przedsięwzięcia zdecydował, że metoda tworzenia Community of Practice stała się stałym składnikiem uczącej się organizacji ${ }^{10}$.

Wnioski z badań, pomimo specyfiki amerykańskiej, w dużej mierze można przenieść na grunt polski. Wprawdzie nie opracowano jeszcze ogólnych standardów umiejętności informacyjnych dla polskich szkół wyższych (poza nielicznymi próbami, takimi jak propozycje standardów IL dla wyższych szkół medycznych ${ }^{11}$ ), niemniej podejmowane są starania o zaszczepienie tych idei na gruncie polskim. W większości polskich wyższych uczelni w programach nauczania znajdują się przedmioty uczące umiejętności informacyjnych. Na przykład na kierunkach pedagogicznych aż na 10 uniwersytetach wykładany jest przedmiot o nazwie technologie informacyjne lub technologia informacyjna (na Uniwersytecie Kazimierza Wielkiego w Bydgoszczy Technologia informacyjna z elementami edycji tekstów, na Uniwersytecie Wrocławskim Nowoczesne technologie informacyjne w edukacji dorostych). Na pięciu uniwersytetach (Jagiellońskim, UAM w Poznaniu,

7 B. J. D'Angelo, B. M. Maid, Moving beyond definitions: Implementing information literacy across the curriculum, "The Journal of Academic Librarianship" 2004, nr 3 (30), s. 212-217.

8 E. Parsloe, M. Wray, Trener i mentor: udział coachingu i mentoringu w doskonaleniu procesu uczenia się, Kraków 2008, s. 82.

9 Tamże, s. 83.

10 K. J. Henrich, R. Attebury, Communities of Practice at an Academic Library: A New Approach to Mentoring at the University of Idaho, "The Journal of Academic Librarianship" 2007, nr 2 (36), s. 158-165.

11 A. Grygorowicz, E. Kraszewska, Propozycje standardów w zakresie edukacji użytkowników polskich bibliotek medycznych, „Annales Academiae Medicae Gedanensis” 2007, nr 37, s. 167-173, http://www.annales.gumed.edu.pl/attachment/ attachment/5151/19-an37_Grygorowicz-Propozycje_stand.pdf, 5.05.2011. 
Warszawskim, Marii Curie-Skłodowskiej w Lublinie, Śląskim) przedmiot ten został włączony do systemu punktów kredytowych i ma 2 punkty (zgodnie z ustaleniami ministrów szkolnictwa wyższego państw UE). Co do pozostałych uczelni brakuje danych ${ }^{12}$.

Na polskich uczelniach wyższych bardzo ważną rolę w kształceniu umiejętności informacyjnych studentów odgrywają biblioteki. Podejmowane przez nie działania to: organizowanie na szeroką skalę szkoleń bibliotecznych na różnym poziomie zaawansowania (od podstawowych dla studentów I roku, po zaawansowane dla piszących prace licencjackie, magisterskie i doktorskie), rozwijanie e-learningu (większość bibliotek akademickich posiada własne platformy e-learningowe) oraz indywidualna praca z czytelnikiem, a także inne formy edukacyjne, jak wystawy, konkursy, prelekcje itp. Jako, że w wielu krajach funkcjonują autonomiczne organizacje lub komórki w organizacjach bibliotekarskich, zajmujące się zagadnieniami IL, w Polsce Zarząd Główny Stowarzyszenia Bibliotekarzy Polskich zaaprobował w 2010 r. powołanie Komisji ds. Edukacji Informacyjnej. Celem jest wprowadzenie IL na grunt polski przy wykorzystaniu bogatych doświadczeń zagranicznych $\mathrm{w}$ tym zakresie. Inną ciekawą inicjatywą jest projekt EMPATIC EMpowering Autonomous Learning through Information Competencies, w którym uczestniczą organizacje z pięciu europejskich krajów, w tym Instytut Informacji Naukowej i Bibliotekoznawstwa UJ, realizowany w ramach Lifelong Learning Programme. Celem jest wywarcie wpływu na proces wdrażania nowych paradygmatów nauczania i strategicznego myślenia o reformie programów kształcenia poprzez zebranie i ocenę rezultatów dotychczas przeprowadzonych projektów związanych z rozwijaniem kompetencji informacyjnych realizowanych w sektorach oświaty, szkolnictwa wyższego, kształcenia dorosłych oraz kształcenia zawodowego. Projekt zakłada wykorzystanie uzyskanych rezultatów do wywarcia wpływu na zmianę sposobu postrzegania problematyki kształcenia w zakresie kompetencji informacyjnych wśród decydentów w Europie ${ }^{13}$.

Pojawia się jednak zupełnie inny problem. Rozwój umiejętności informacyjnych często wcale nie jest studentom potrzebny. Obserwowane zjawisko „supermarketyzacji” czy „mcdonaldyzacji" uczelni wyższych dotyczy nie tylko szkół prywatnych. Student, aby się utrzymać i móc studiować, musi pracować i nie ma czasu na solidne przyłożenie się do zdobywania wiedzy. Pracownicy naukowi często także nie mają czasu, zatrudnieni na kilku etatach, przeciążeni liczbą realizowanych godzin dydaktycznych i bardzo rozległą tematyką zajęć, nie motywują swoich studentów do prawdziwego studiowania. Kończy się na tym, że ci ostatni domagają się, aby przekazywana wiedza była atrakcyjna, praktyczna, dobrze przekazana i łatwo przyswajalna. Dlatego wcale nie dziwi porównanie uniwersytetu do supermarketu, jako miejsca, w którym towary są łatwo dostępne i mogą być konsumowane ${ }^{14}$. W tych warunkach nie ma szans na to, aby wykształcić u studentów jakiekolwiek umiejętności informacyjne. Student wpada do biblioteki uczelnianej tylko po to, aby odszukać zadany tekst i odbić go na ksero. Często nawet nie musi zaglądać do biblioteki, bo gotowe materiały znajdzie w punkcie kserograficznym. Efekt jest taki, że na zajęciach sprawdzana jest jedynie umiejętność czytania ze zrozumieniem, a i z tym bywają problemy. Widać tu wyraźnie, jak bardzo brakuje w bibliotekach cyfrowych i repozytoriach aktualnej literatury. Ograniczenia wynikające z praw autorskich i brak pieniędzy na kupowanie licencji od autorów powodują powstanie czarnej dziury - braku XX i XXI-wiecznej literatury naukowej,

12 Dane na podstawie programów studiów zamieszczonych na stronach internetowych uczelni (kwiecień 2011).

13 Projekt EMPATIC zakłada realizację warsztatów w każdym kraju (w Polsce - Międzynarodowe Warsztaty "Kształtowanie kompetencji informacyjnych w szkolnictwie" Kraków, czerwiec 2011), http://empat-ic.eu/pol, 5.05.2011.

14 D. A. Hejwosz, Uniwersytet jako fabryka i supermarket. Kierunki, szanse i zagrożenia wynikajace z komercjalizacji uniwersytetu, [w:] A. Kobylarek, J. Semków (red.), Edukacja uniwersytecka w warunkach zmiany kulturowej, Wrocław 2008, s. 57. 
a taka jest najbardziej poszukiwana przez studentów. Kto powinien z tym walczyć? Jest to zadanie dla bibliotekarzy zatrudnionych w bibliotekach akademickich. Ważne jest rozpropagowanie wśród pracowników naukowych uczelni idei wolnego dostępu do źródeł i przekonanie ich do celowości umieszczania swoich publikacji w bibliotekach cyfrowych i repozytoriach. Ważne jest też dotarcie do użytkowników, w czym ogromną rolę spełnia strona internetowa biblioteki - brama do przestrzeni edukacyjnej tzw. knowledge space uczelni ${ }^{15}$. E-learning pomaga potencjalnym czytelnikom wkroczyć w świat elektronicznych źródeł informacji i ułatwia zdobycie kompetencji informacyjnych. Zresztą idea kształcenia w tym zakresie wybiega poza środowisko akademickie. Coraz częściej odnosi się ją do ogólnej koncepcji kształcenia - od szkoły podstawowej, poprzez średnią i wyższa, aż do kształcenia ustawicznego, a jak wynika z doświadczeń amerykańskich - wszystkie formy nauczania są skuteczne i po prostu należy je podjąć. Wnioski płynące z przeprowadzonych za oceanem badań $\mathrm{w}$ dużej części można wykorzystać także u nas. W uczeniu umiejętności informacyjnych na uczelniach wyższych nie wystarczy ograniczone do dwugodzinnych zajęć przysposobienie biblioteczne. Programy przedmiotów z tej dziedziny, takich jak Technologie informacyjne, powinny zostać wzbogacone o standardy IL, opracowane na przykład w oparciu o zalecenia ACRL. Trzeba propagować e-learning oraz inne metody nauczania, a także ścisłą współpracę bibliotekarzy i pracowników naukowych. Niezbędna jest też popularyzacja idei information literacy wśród studentów i doktorantów, ponieważ to im wiedza z tego zakresu jest najbardziej potrzebna, zarówno w procesie kształcenia akademickiego, jak i w codziennym życiu w społeczeństwie opartym na wiedzy. Podsumowując dotychczasowe rozważania warto przytoczyć fragment tekstu autorstwa prof. dr hab. Jerzego Semkowa, w pełni oddający istotę problemu: „Droga do lepszego poznania i rozumienia świata wiedzie przez edukację bazującą na nowym paradygmacie - wiedzy o sposobach i możliwościach zdobywania wiedzy niezbędnej do dobrego funkcjonowania w zmiennej oraz napiętnowanej ryzykiem rzeczywistości"16.

\section{BibLIOGRAFIA}

Anderson K., May F. A., Does the Method of Instruction Matter? An Experimental Examination of Information Literacy in the Online, Blended and Face-to-Face Classrooms, "The Journal of Academic Librarianship" 2010, nr 6 (36).

D'Angelo B. J., Maid B. M., Moving beyond definitions: Implementing information literacy across the curriculum, "The Journal of Academic Librarianship" 2004, nr 3 (30).

Fabiś A., Stopińska A. (red.), Uczacy się dorosły w zmieniajacym się świecie, Bielsko-Biała 2010.

Hejwosz D. A., Uniwersytet jako fabryka i supermarket. Kierunki, szanse i zagrożenia wynikajace z komercjalizacji uniwersytetu,[w:] A. Kobylarek, J. Semków (red.), Edukacja uniwersytecka w warunkach zmiany kulturowej, Wrocław 2008.

Henrich K. J., Attebury R., Communities of Practice at an Academic Library: A New Approach to Mentoring at the University of Idaho, "The Journal of Academic Librarianship" 2007, nr 2 (36).

Kobylarek A., Semków J. (red.), Edukacja uniwersytecka w warunkach zmiany kulturowej, Wrocław 2008.

Parsloe E., Wray M., Trener i mentor: udział coachingu i mentoringu w doskonaleniu procesu uczenia się, Kraków 2008.

Semków J., Znaczenie uczenia się człowieka dorosłego z perspektyww jego potrzeb i aspiracji w okresie szybkich przemian cywilizacyjnych i kulturowych, [w:] Fabiś A., Stopińska A. (red.), Uczacy się dorosty w zmieniającym się świecie, Bielsko-Biała 2010.

Ward D., Revisioning information literacy from lifelong meaning, "The Journal of Academic Librarianship" 2006, nr 4 (32).

15 P. Marcinkowski, Bibliotekarz w akademickim knowledge space, http://repozytorium.amu.edu.pl/jspui/bitstream/10593/171/1/Bibliotekarz\%20w\%akademickim\%knowledge\%20space.pdf, 5.05.2011.

16 J. Semków, Znaczenie uczenia się człowieka dorosłego z perspektywy jego potrzeb i aspiracji w okresie szybkich przemian cywilizacyjnych i kulturowych, [w:] A. Fabiś, A. Stopińska (red.), Uczacy się dorosty w zmieniajacym się śziecie, Bielsko- Biała 2010, s. 22. 


\section{NetOgRAFia}

Deklaracja Bolońska i co dalej: zbiór komunikatów, wytycznych i sugestii. Materiały ze strony internetowej MENiS http://www. menis.gov.pl, Konferencja Rektorów Uniwersytetów Polskich, Poznań 2004, http://www.uka.amu.edu.pl/pictures/ bolonia.pdf, 5.05.2011.

Grygorowicz A., Kraszewska E., Propozycje standardów w zakresie edukacji użytkowników polskich bibliotek medycznych, „Annales Academiae Medicae Gedanensis" 2007, nr 37, http://www.ala.org/acrl/ilomstan.ala/acrl/acrlstandards, 5.05.2011. http://empat-ic.eu/pol, 5.05.2011.

http://www.annales.gumed.edu.pl/attachment/attachment/5151/19-an37_Grygorowicz-Propozycje_stand.pdf, 5.05.2011.

Konieczna D., Biblioteka akademicka jako instytucja promująca kształcenie, http://www.library.put.poznan.pl/2005/pdf/3_4. pdf, 5.05.2011.

Marcinkowski P., Bibliotekarz wakademickim knowledge space, http://repozytorium.amu.edu.pl/jspui/bitstream/10593/171/1/ Bibliotekarz\%20w\%akademickim\%knowledge\%20space.pdf, 5.05.2011.

Rozkosz E., Alfabetyzacja informacyjna, http://alfabetyzacjainformacyjna.blogspot.com/2011/information-literacy-po-polski-czyli.html, 5.05.2011.

\section{Słowa kluczowe}

umiejętności informacyjne, kształcenie ustawiczne, e-learning, mentoring, biblioteki szkół wyższych.

\section{STRESZCZENiE}

Lawinowy rozwój technologii informatycznych i komunikacyjnych w początkach XXI wieku wpłynął na usprawnienie komunikacji, procesów kształcenia, prowadzenie badań naukowych. Stworzył nowe możliwości rozwoju osobistego i zawodowego. Spowodował również powstanie tzw. szumu informacyjnego. Konieczne stało się kształcenie użytkowników informacji. Posiadanie umiejętności informacyjnych jest niezbędne nie tylko w procesie kształcenia akademickiego, ale także w procesie kształcenia ustawicznego. Największe doświadczenie w tym zakresie mają uczelnie amerykańskie, gdzie opracowano standardy kompetencji informacyjnych dla studentów. Wiele z doświadczeń amerykańskich można przenieść na grunt polski, jako że także w naszym kraju tematyka ta spotyka się z coraz większym zainteresowaniem, zarówno kręgach naukowych, jak i bibliotekarskich.

\section{IT EDUCATION AT UNIVERSITY - BETWEEN THE IDEAL AND REALITY. Can we use the American experiences in Poland?}

\section{Keywords}

Informative abilities, continuous education, e-learning, mentoring, college libraries

\section{Summary}

Rapid development of information and communication technologies at the beginning of $21^{\text {st }}$ century has influenced on improvement of communication, learning processes, scientific research methods. It has brought new possibilities for personal and professional development. It has also caused the phenomenon of information noise. The education of the users of information has become necessary. Information skills are crucial not only in the process of university education but also in lifelong education. In this area the most experienced are American universities, which developed the standards of student information skills. Many of these experiences could be implemented in Poland, because here this issue is becoming more interesting for scientists and librarians. 